\title{
Gallium Ga 68-NEB
}

National Cancer Institute

\section{Source}

National Cancer Institute. Gallium Ga 68-NEB. NCI Thesaurus. Code C123821.

A radiotracer composed of a truncated form of the azo dye Evans blue (EB) conjug ated, via a 1,4,7-triazacyclononane-N,N',N"-triacetic acid (NOTA) linker (NEB), to the radioisotope gallium $\mathrm{Ga} 68$, with potential blood pool imag ing activity for use in positron emission tomography (PET). Upon administration of gallium Ga 68-NEB, the NEB moiety, which has high affinity for serum albumin, targets and forms a complex with albumin. Upon PET, the lymph nodes (LN) and lymphatic vessels as well as other desired tissues can be visualized. 